\title{
Audit Delay Analysis to Support the Effectiveness of Company's Financial Reporting on Manufacturing Companies Listed On The Indonesia Stock Exchange
}

\author{
Tjahjani Murdijaningsih*, Siti Muntahanah \\ Faculty of Economics and Business at UNWIKU, Kampus Karang salam UNWIKU ${ }^{1}$ \\ *correspondence email: cahyaniyubi@gmail.com
}

\begin{abstract}
Abstrak. Setiap perusahaan yang terdaftar di Bursa Efek Indonesia wajib menyampaikan laporan keuangan secara berkala. Laporan keuangan tersebut disampaikan selambat-lambatnya pada akhir bulan ketiga sejak tanggal berakhirnya tahun buku. Dalam kenyataannya, tidak semua perusahaan menyampaikan laporan tepat pada waktu dikarenakan adanya keterlambatan laporan audit, sehingga pelaporan keuangan perusahaan tidak efektif. Keterlambatan pelaporan keuangan sangat berhubungan dengan audit delay. Penelitian ini bertujuan untuk menganalisis faktor-faktor yang berpengaruh terhadap waktu yang digunakan dalam audit atas laporan keuangan. Sampel dalam penelitian ini adalah 15 perusahaan industri real estate dan properti yang terdaftar di Bursa Efek Indonesia periode tahun 2013-2017. Penentuan sampel dalam penelitian ini menggunakan metode purposive sapling, Analisis yang digunakan adalah analisis regresi berganda. Hasil penelitian menunjukkan bahwa firm size tidak berpengaruh signifikan terhadap audit delay. Sementara itu, profitabilitas berpengaruh negative dan ukuran Kantor Akuntan Publik berpengaruh positive signifikan terhadap audit delay. Besar kecilnya perusahaan tidak menentukan lamanya audit terhadap laporan keuangan, sehingga untuk meningkatkan ketepatan penyampaian laporan keuangan, yang harus lebih diperhatikan adalah tingkat profitabilitas dan kantor akuntan publik yang akan digunakan.
\end{abstract}

Kata Kunci: Audit Delay, Size, Profitabilitas, dan Ukuran KAP

\begin{abstract}
Every company listed on the Indonesia Stock Exchange is required to submit financial reports periodically. The financial statements shall be submitted no later than the end of the third month from the end date of the financial year. In reality, not all companies submit the right reports on time because of the audit reports, so that the company's financial reporting is not effective. Delays in financial reporting are closely related to audit delays. This study aims to analyze the factors that affect the time spent in auditing financial statements. The sample in this study were 15 real estate and property industrial companies listed on the Indonesia Stock Exchange for the period 2013-2017. Determination of the sample in this study using the purposive sapling method. The analysis used is multiple regression analysis. The results showed that company size had no significant effect on audit delay. Meanwhile, profitability has a negative effect and the size of the public accounting firm has a significant positive effect on audit delay. The size of the company cannot determine the audit of the financial statements to improve the accuracy of the submission of financial statements. What must be paid more attention is the level of profitability and the public accounting firm that will be used.
\end{abstract}

Keywords: Audit Delay, Size, Profitability, and KAP Size

\section{Introduction}

Indonesia as a developing country must always increase competitiveness with other countries because of the Asean Economic Community (AEC) which has been implemented. The development of the country is supported by the increasing effectiveness of companies as supporters in supporting the nation's economy. The development of companies in Indonesia is characterized by the increasing number of companies going public. Until now, hundreds of companies are listed on the Indonesia Stock Exchange. The rapid development of activities on the Indonesia Stock Exchange has resulted in an increase in demand for financial statement audits in an effective and efficient manner. Every company going public is required to submit financial reports prepared in accordance with Financial Accounting Standards that have been audited by public accountants registered with the Capital Market Supervisory Agency. Every company listed on the Indonesia Stock Exchange is required to submit financial reports periodically. This is as stipulated in the Decree of the Chairman of Bapepam Number KEP 36 / PM / 2003 concerning the obligation to submit financial reports periodically. Financial reports are submitted to Bapepam no later than the end of the third month from the end date of the financial year. Audit delay is the time span for completion of the audit of annual financial statement which is measured based on the number of days required to obtain an independent auditor's report on the audit of the company's annual financial report, starting from the closing date of the company's financial year, which is as of December 31, until the date stated on the independent auditor's report. Audit delay that exceeds the stipulated deadline will result in delays in the publication of financial reports. This can have a negative impact on the company, investors and other related parties. A financial report will have a beneficial value if it is submitted accurately and precisely. 
The process of achieving punctuality in the presentation of independent auditors' reports is becoming increasingly uneasy, given the increasing development of public companies in Indonesia. These obstacles and timeliness can also be seen from the Public Accountant Audit Standard in the third standard, namely to be able to use carefully and thoroughly their professional skills in auditing and in preparing audit reports (Mulyadi, 2014). There are various factors that can affect audit delay. Ningsih \& Widhiyani (2015) examined the effect of company characteristics and auditor characteristics on audit delays. The variables studied included the size of the company, profitability, while the characteristics of the auditors were the audit committee. Based on this, the factors that can affect audit delay include firm size, profitability and the size of the Public Accounting Firm (KAP). This is also supported by several other previous research results.

Harjanto (2017) in his research concluded that the internal factors that affect audit delay are company size, profitability and solvency and external factors are the size of the public accounting firm, the results of the study stated that the variables of profitability, solvency, internal auditors have no influence on audit delays, while the size of the public accounting firm has a positive effect on audit delays. The results of research by Juanita \& Satwoko (2012) showed that the profit or loss experienced by the company is a factor that determines the occurrence of audit delays, as well as for profitability and auditor size also affects audit delays. The size of the company and the company audited by Big Four KAP has no significant effect on audit delay, while the profit or loss experienced by the company has a significant effect on audit delays. Santoso (2013) analyzed The Size Of The Company, Profitability, Debt To Equity Ratio, Contingency on audit delay in companies listed on the Indonesia Stock Exchange. The results of the analysis prove that the size of the company has a significant negative effect on audit delay, while the other variables have no effect.

Based on some of the previous research results mentioned above, there is a research gap where there are inconsistencies in the research results. Therefore, this research is interesting to do to find out the more consistent influence of several variables that affect audit delay, especially the size, profitability, and size of Public Accounting Firm (KAP). This research is important to be carried out so that the company is timely in submitting financial reports and becomes material for information in making decisions appropriately. Information that is delivered on time will support managers in dealing with uncertainties that occur in the work environment.

\section{Methods}

The populations of this research are real estate and property industrial companies listed on the Indonesia Stock Exchange for the period 2013-2017. The samples were determined by purposive sampling method. The criteria used are as follows:

- The company is listed on the Indonesia Stock Exchange during the observation period, namely 2013-2017.

- Companies that issue annual financial reports that are audited for five consecutive years, namely 2013, 2014, 2015. 2016 and 2017

- Companies sampled have complete data in accordance with the models or variables used in this study.

The dependent variable in this study is audit delay, which is the length of time to complete the audit measured from the closing date of the financial year to the date of issuance of the financial reports.

Independent Variable

- Firm Size, Firm Size is a scale that shows the classification of the size of the company. The size can systematically be formulated as follows: Firm Size $=$ Ln Total Assets

- Profitability (ROA), The measurement of profitability in this study uses Return On Asset (ROA), referring to the research of Widyantari and Wirakusuma (2012). ROA describes asset turnover as measured by total assets. The formula is: $\mathrm{ROA}=$ Net Income $/$ Total Assets

- KAP Size, Auditor size is the level of the auditor's reputation. The size is associated with KAP The Big Four, which includes: Large, if the company audited by KAP The Big Four. Medium, if the company audited by auditors affiliated with KAP The Big Four. Small, if the company audited by an auditor who is not affiliated with KAP The Big Four.

This study uses multiple linear regression method with panel data approach to analyze the effect of the independent variable on the dependent variable with the following regression equation:

$\mathrm{Y}_{\mathrm{it}}=\mathrm{b}_{\mathrm{o}}+\mathrm{b}_{1} \mathrm{X}_{1 \mathrm{it}}+\mathrm{b}_{2} \mathrm{X}_{2 \mathrm{it}}+\mathrm{b} 3 \mathrm{X} 3_{\mathrm{it}}+\mathrm{e}_{\mathrm{it}}$

$\mathrm{Y}=$ Audit Delay; $\mathrm{b}_{\mathrm{o}}=$ Constant; $\mathrm{b}_{1,2,3}=$ Independent variable regression coefficient; $\mathrm{X}_{1}=$ Firm Size; $\mathrm{X}_{2}=$ Profitability; $\mathrm{X}_{3}=$ KAP Size; $\mathrm{e}=$ error

The panel data model equation above is then estimated using the common effect, fixed effect and random effect model approaches, while to determine which method is more suitable for this study, the Chow test, Hausman test and LM test are used (Ghozali, 2016). The next step is to test the classical assumptions. The classical assumption test of the regression model used is conducted in order to find out whether the regression model is a good regression 
Tjahjani Murdijaningsih dan Siti Muntahanah, Audit Delay Analysis To Support The Effectiveness of Company's Financial Reporting on Manufacturing Companies Listed on The Indonesia Stock Exchange

model or not. This research model, the classical assumption test, used the normality test, multicollinearity, heteroscedasticity, and autocorrelation.

\section{Discussion}

Table 1.

Table 1. The output of fixed effect model

\begin{tabular}{|lllll|}
\hline Variable & Coefficient & $\mathrm{t}$ count & $\mathrm{t}$ table & Prob. \\
Firm Size & $-0,002$ & $-1,040$ & 1,669 & 0,302 \\
Profitability & $-0,007$ & $-2,188$ & 1,669 & 0,032 \\
KAP Size & 12.434 & 4,295 & 1,669 & 0,000 \\
\hline Constant & $=80,137$ & & & \\
Square & $=0,250$ & & & \\
F count & $=7,878$ & & \\
\hline
\end{tabular}

Source: processed data

Firm Size has a regression coefficient of -0.002 and a probability value of 0.302 . This shows that firm size has no significant effect on audit delays. The results of this study prove that firm size does not have a significant negative effect on the audit delay of property and real estate sector service companies listed on the Indonesia Stock Exchange during 2013-2017. This indicates that the greater the asset value of a company, the shorter the audit delay will be. This is because the larger the company, the company has a good internal control system so as to reduce the level of errors in financial reports so that auditing of financial statements can be conducted more quickly. These support the research results of Nurahman (2017), Ariyani (2014), Puspitasari \& Sari (2012), Althaf (2016), Wirakusuma (2017), Arifudin (2017) and Mohammad (2014) which show that firm size has a negative effect. significant on audit delay. Profitability has a regression coefficient of -0.007 and a probability value of 0.032 . This shows that profitability has a significant negative effect on the audit delay of property and real estate sector service companies listed on the Indonesia Stock Exchange during 2013-2017. This indicates that the higher the audit delay, the lower the profitability will be. Companies that have high profitability tend to have short audit time delays because high profitability is good news so that companies will no longer delay publishing their financial reports. The results of this study are in line with research conducted by Ariyani \& Budiartha (2014), Carbaja \& Yadnyana (2015), Lianto \& Kusuma (2010), Amani (2016), Artaningrum, I Ketut and Made (2017), Kartika, (2011) and Mouna and Anis (2013), which show that profitability has a significant negative effect on audit delay.

The KAP size has a regression coefficient of 12,434 and a probability value of 0,000 . This value shows that the KAP size has a significant positive effect on the audit delay of property and real estate sector service companies listed on the Indonesia Stock Exchange during 2013-2017. This indicates that the higher the audit delay, the higher the KAP size will be. This is because KAP the big four and non-big four have different characteristics. KAP the big four will work more professionally than the non-big four. KAP the big four will work more effectively and efficiently so that it will be faster in submitting audit reports. These support the results of research from Nurahman (2017), which shows that KAP size has a significant positive effect on audit delay

\section{Conclusion}

The company has an obligation to submit financial reports on time so that it can be used as information material in making appropriate decisions. Timely information will support managers in dealing with uncertainties that occur in the work environment. The results showed that firm size has no effect on audit delay. Meanwhile, profitability has a negative effect and the size of the Public Accounting Firm has a significant positive effect on audit delay. Based on the results of the research, it is known that the size of the company has no effect on audit delay, however to improve the timeliness of submitting financial statements, the company must pay more attention to the level of profitability of the company and which accounting firm will be used by the company. For future researchers, it is expected to improve research on variables that can affect audit delay by adding independent variables and researchers can increase the length of their research period, and can also conduct audit delay research on other subsector companies.

\section{References}

Amani, F, A. (2016). Pengaruh Ukuran Perusahaan, Profitabilitas, Opini Audit, Dan Umur Perusahaan Terhadap Audit Delay (Studi Empiris pada Perusahaan Property dan Real Estate yang Terdaftar di Bursa Efek Indonesia pada Tahun 2012-2014). Jurnal Nominal 5(1): 135-150 
Tjahjani Murdijaningsih dan Siti Muntahanah, Audit Delay Analysis To Support The Effectiveness of Company's Financial Reporting on Manufacturing Companies Listed on The Indonesia Stock Exchange

Apriyana, N. (2017). Pengaruh Profitabilitas, Solvabilitas, Ukuran Perusahaan, Dan Ukuran KAP Terhadap Audit Delay. Jurnal Nominal 6(2): 108-124

Ariyani, N, N, T, D., \& Budiartha. I, K. (2014). Pengaruh Profitabilitas, Ukuran Perusahaan, Kompleksitas Operasi Perusahaan Dan Reputasi Kap Terhadap Audit Report Lag Pada Perusahaan Manufaktur. E-Jurnal Akuntansi Universitas Udayana 8(2): 217-230

Artaningrum, R.G., Budiarta, I. K., \& Wirakusuma, M. G. (2017). Pengaruh Profitabilitas, Solvanilitas, Likuiditas, Ukuran Perusahaan dan Pergantian Manajemen Pada Audit Report Lag Perusahaan Perbankan. E-Jurnal Akuntansi Universitas Udayana 6(3): 1079-1108

Carbaja, L. K. I \& Yadnyana, I. K (2015). Pengaruh Profitabilitas, Ukuran Perusahaan, Reputasi Kap, Dan Pergantian Auditor Pada Ketidaktepatwaktuan Pelaporan Keuangan. E-Jurnal Akuntansi Universitas Udayana. 13(2): 615-624.

Ghozali, I. (2016). Aplikasi Analisis Multivariate dengan Program IBM SPSS (Edisi Ke 4). Semarang: Badan Penerbit Universitas Diponogoro.

Harjanto, K. (2018). Pengaruh Ukuran Perusahaan, Profitabilitas, Solvabilitas, dan Ukuran Kantor Akuntan Publik terhadap Audit Delay. Ultimaccounting : Jurnal Ilmu Akuntansi,9(2), 33-49. https://doi.org/https://doi.org/10.31937/akuntansi.v9i2.728

Juanita, J, G., \& Satwiko, R. (2012), Pengaruh Ukuran Kantor Akuntan Publik, Kepemilikan, Laba Rugi, Profitabilitas Dan Solvabilitas Terhadap Audit Report Lag, Jurnal Bisnis Dan Akuntansi, 14(1): 31-40. https://doi.org/10.34208/jba.v14i1.103

Kartika, A. (2011). Faktor-Faktor Yang Mempengaruhi Audit Delay Pada Perusahaan Manufaktur Yang Terdaftar Di BEI. Dinamika Keuangan dan Perbankan. 3(2): 152-171.

Lianto, N., \& Kusuma, B. H. (2010). Faktor-Faktor Yang Berpengaruh Terhadap Audit Report Lag. Jurnal Bisnis dan Akuntansi. 12(2): 97-106. https://doi.org/10.34208/jba.v12i2.188

Mouna, A., \& Anis, J. (2013). "Financial Reporting Delay and Investors Behavior: Evidence from Tunisia". International Journal Management Bussines 3 (1). 57-67

Mulyadi. 2014. Auditing. Buku 1 Edisi Keenam. Jakarta: Salemba Empat.

Neraca. (2015). Payah 52 Emiten Telat Laporkan Keungan.

Ningsih, I, G, A, P, S., \& Widhiyani, N, L, S. (2015), Pengaruh Ukuran Perusahaan, Laba Operasi, Solvabilitas, Dan Komite Audit Pada Audit Delay. E-Jurnal Akuntansi Universitas Udayana 12(3): 481- 495.

Puspitasari, E., \& Sari, A. N. (2012). Pengaruh Karakteristik Perusahaan Terhadap Lamanya Waktu Penyelesaian Audit (Audit Delay) Pada Perusahaan Manufaktur Yang Terdaftar Di Bursa Efek Indonesia, Jurnal Akuntansi Dan Auditing, 9(1): 31-42, Https://Doi.Org/10.14710/Jaa.9.1.31-42

Santoso, F, K. (2013). Analisis Faktor-Faktor Yang Mempengaruhi Audit Delay Pada Perusahaan Di Sektor Keuangan. Berkala Ilmiah Mahasiswa Akuntansi. 1(2):89-95.

Zureigat, Q, M. (2014). Factors Associated with Audit Reports in Saudi Arabia. Global Journal of Management and Business Research: D Accounting and Auditing. 14(5): 66-75 